\title{
ARID1A Gene Mutation
}

National Cancer Institute

\section{Source}

National Cancer Institute. ARID1A Gene Mutation. NCI Thesaurus. Code C157462.

A change in the nucleotide sequence of the ARID1A gene. 